\title{
Using a mobile laboratory to characterize the distribution and transport of sulfur dioxide in and around Beijing
}

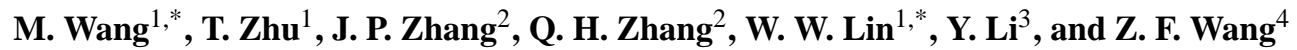 \\ ${ }^{1}$ State Key Laboratory of Environmental Simulation and Pollution Control, College of Environmental Sciences and \\ Engineering, Peking University, Beijing, 100871, China \\ ${ }^{2}$ Department of Atmospheric and Oceanic Sciences, School of Physics, Peking University, Beijing, 100871, China \\ ${ }^{3}$ Chinese Academy of Meteorological Science, Beijing, 100081, China \\ ${ }^{4}$ Nansen-Zhu International Research Centre, Institute of Atmospheric Physics, Chinese Academy of Sciences, Beijing, \\ 100871, China \\ * present address: Institute for Risk Assessment Sciences, Utrecht University, The Netherlands
}

Received: 30 March 2011 - Published in Atmos. Chem. Phys. Discuss.: 6 June 2011

Revised: 4 November 2011 - Accepted: 11 November 2011 - Published: 22 November 2011

\begin{abstract}
Megacities are places with intensive human activity and energy consumption. To reduce air pollution, many megacities have relocated energy supplies and polluted industries to their outer regions. However, regional transport then becomes an important source of air pollution in megacities. To improve air quality before and during the $2008 \mathrm{Bei}-$ jing Olympics, a wide range of control strategies were implemented, including the relocation of polluting industries. High sulfur dioxide $\left(\mathrm{SO}_{2}\right)$ concentrations were occasionally observed during this period. Potential sources from southern regions of Beijing were indicated by backward trajectories model and urban/rural stationary measurements, but direct evidence was lacking. Here we used a mobile laboratory to characterize the spatial distribution and regional transport of $\mathrm{SO}_{2}$ to Beijing during the Campaign for Air Quality Research in Beijing and the Surrounding Region (CAREBEIJING)-2008. Among the five days chosen for the case studies during the Olympic air pollution control period, four had high $\mathrm{SO}_{2}$ concentrations (6, 20 August and 3, 4 September 2008) while one had low $\mathrm{SO}_{2}$ concentration (11 September 2008). The average values of $\mathrm{SO}_{2}$ during the low $\mathrm{SO}_{2}$ concentration day were $3.9 \mathrm{ppb}$, much lower than during the high concentration days $(7.8 \mathrm{ppb})$. This result implied an impact by regional transport from outside Beijing. During these days, we captured transport events of $\mathrm{SO}_{2}$ from areas south of Beijing, with a clear decrease in $\mathrm{SO}_{2}$ concen-
\end{abstract}

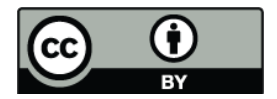

Correspondence to: $\mathrm{T}$. Zhu

(tzhu@pku.edu.cn) trations southeast of the 6th to 4th Ring Roads around Beijing and along the $140 \mathrm{~km}$ highway from Tianjin to Beijing. The influx of $\mathrm{SO}_{2}$ through the 4th to 6th Ring Roads ranged from 2.1 to $4.6 \mathrm{~kg} \mathrm{~s}^{-1}$ on 4 September and 0.2 to $1.6 \mathrm{~kg} \mathrm{~s}^{-1}$ on 20 August 2008. The differences of influx in days were due to the variations of emission changes, transport directions and dilutions. Locally emitted $\mathrm{SO}_{2}$ from a source located along Jingshi Highway outside the southwest section of the 5th Ring Road of Beijing was identified using wind field data generated by the Weather Research and Forecasting model and the measured particle size distribution, with an estimated flux of $0.1 \mathrm{~kg} \mathrm{~s}^{-1}$ to Beijing. Estimated uncertainties for $\mathrm{SO}_{2}$ influx were approximately $31 \%$.

\section{Introduction}

Sulfur dioxide $\left(\mathrm{SO}_{2}\right)$ is one of the most important precursors of secondary aerosols in the atmosphere. It is responsible for severe air pollution, leading to degraded visibility, changes in the radiation budget, and acid rain (Wang et al., 2008; Zhang et al., 2004a; Ramanathan and Crutzen, 2003). In addition, $\mathrm{SO}_{2}$ is harmful to human health (Brunekreef and Holgate, 2002) and may cause increased respiratory diseases, reduced pulmonary function, low birth weight, and mortality (Xu et al., 1998).

Rapid economic development, industrialization, and urbanization have occurred within and around the megacity of Beijing, increasing demands for fossil fuel consumption (Ohara et al., 2007), which is the main source of $\mathrm{SO}_{2}$.

Published by Copernicus Publications on behalf of the European Geosciences Union. 
In 2008, the annual average energy consumption levels in Beijing, Tianjin, and the surrounding provinces of Heibei, Shanxi, and Shandong were 63.4 (Beijing Statistical Yearbook, 2009), 53.6 (Tianjin Statistical Yearbook, 2009), 242.2 (Hebei Statistical Yearbook, 2009), 268.8 (Shanxi Statistical Yearbook, 2009), and 125.1 (Shandong Statistical Yearbook, 2009) million tons of standard coal, respectively. To improve air quality and maintain clean air throughout the 2008 Beijing Olympic Games, the Beijing municipal government implemented comprehensive long- and short-term air pollution control measures. The measures included moving heavy polluters out of the city, using low sulfur coal and high standard fuel (e.g. Euro IV), reducing the number of on-road vehicles, and freezing construction activities before and during the Olympic Games. While significant decreases in $\mathrm{SO}_{2}$ were reported during the Olympics (Wang et al., 2009a, b; Qin et al., 2009), periods with relatively high $\mathrm{SO}_{2}$ concentrations occasionally occurred during the Olympic period, suggesting an important role of the regional transport of $\mathrm{SO}_{2}$ emitted outside Beijing.

Previous studies have reported that both local emission and regional transport sources contribute to $\mathrm{SO}_{2}$ in Beijing (Zhang et al., 2004b; Xu et al., 2004; Sun et al., 2004). Rural/urban stationary (Liu et al., 2008; Guo et al., 2010) and tower observations (Sun et al., 2009) in Beijing have revealed that high wind speeds from southern areas might play a vital role in the increase of $\mathrm{SO}_{2}$ concentrations in Beijing. An et al. (2007) used the Community Multiscale Air Quality (CMAQ) model to simulate the regional transport of $\mathrm{SO}_{2}$ and its flux pathway during a heavy pollution episode. They estimated that the southeast and southern areas of Beijing contributed $26 \%$ and $18 \%$ of $\mathrm{SO}_{2}$ to the city. However, due to uncertainties in the $\mathrm{SO}_{2}$ emission inventory outside Beijing, it is difficult to model the dispersion and transport of $\mathrm{SO}_{2}$ accurately on small scales (Matsui et al., 2009). Thus, direct evidence from spatial distribution measurements is required.

Aircraft-based measurement with fast response instruments is a suitable approach to both studying the spatial distribution and quantifying the regional transport flux of $\mathrm{SO}_{2}$ (Wang et al., 2006; Matvev et al., 2002; Beryrich et al., 1998). In northern China (where Beijing is located), research on $\mathrm{SO}_{2}$ transport using aircraft measurements has focused on large-scale processes ( $\mathrm{Li}$ et al., 2010; Ma et al., 2010; Ding et al., 2009) in the upper boundary layer or in the free troposphere. Given the high cost of aircraft measurement and difficulties in obtaining navigation approval, on-road measurement from mobile laboratories is an optimal method for ground-based spatial distribution measurement. On-road measurement platforms have been specifically designed and used for three types of applications: investigation of emission factors of individual vehicles by chasing studies (Canagaratna et al., 2004; Herndon et al., 2005), examination of the temporal-spatial variations in air pollutants for exposure assessment (Bukowiecki et al., 2002; Weijers et al., 2004), and quantification of local emissions and regional transport flux (Johansson et al., 2009; Rivera et al., 2009). Johansson et al. (2008) and Li et al. (2009) calculated $\mathrm{SO}_{2}$ fluxes from local emissions in Beijing using mobile-based minidifferential optical absorption spectroscopy (DOAS) around the 5th Ring Road of Beijing. However, these calculations were only based on column concentrations of $\mathrm{SO}_{2}$. There is hence a lack of information on the ground level transport and concentrations of other air pollutants.

Here we used an on-road mobile laboratory to measure the spatial distribution of $\mathrm{SO}_{2}$ concentrations and identify transport processes in the southern part of Beijing. These observations were part of the Campaign for Air Quality Research in Beijing and the Surrounding Region-2008 (CAREBEIJIING)-2008. The flux of $\mathrm{SO}_{2}$ from both local emission and regional transport was estimated using wind field data from the Weather Research and Forecasting (WRF) model version 3.1.1.

\section{Methodology}

\subsection{Mobile laboratory and driving routes}

Details of the setup and performance of the instruments installed in the mobile laboratory were described in our previous paper (Wang et al., 2009a). Briefly, a diesel vehicle (IVECO Turin V) was selected as the mobile platform. To minimize the loss of particles in the sampling inlet, an isokinetics inlet system was designed to enhance the sampling efficiency. The instruments onboard provided data on the concentrations of gaseous pollutants $\left(\mathrm{NO}-\mathrm{NO}_{2}-\mathrm{NO}_{\mathrm{x}}\right.$, $\mathrm{SO}_{2}, \mathrm{CO}, \mathrm{CO}_{2}, \mathrm{O}_{3}$ ) (ECOTECH, Australia), black carbon (MAAP, THERMO, USA), particle surface area (Nanoparticle surface area monitor, TSI, USA), particle size distribution (SMPS, DMA 3080 and CPC 3550, TSI, USA), and volatile organic compounds (VOCs; PTR-MS, IONICON, Austria). In this paper only the data of $\mathrm{SO}_{2}$ and SMPS were used (Table 2). The time resolutions of $\mathrm{SO}_{2}$ and SMPS data were $10 \mathrm{~s}$ and $2 \mathrm{~min}$, respectively. Additional instruments included a Global Positioning System (GPS) and meteorological parameters (temperature, humidity, and pressure). The driving speed was $60 \pm 5 \mathrm{~km} \mathrm{~h}^{-1}$.

To characterize the spatial distribution of $\mathrm{SO}_{2}$ and to investigate the regional transport progress of $\mathrm{SO}_{2}$ to Beijing, routes were specially designed at local scale around the south area of Beijing, and at regional scale between Beijing and Tianjin megacities (Fig. 1). The details of routes and monitoring information are listed in Table 1. Five days were chosen for the measurements, and in general four days (6, 20 August and 3, 4 September 2008) showed high $\mathrm{SO}_{2}$ concentrations and one day showed low $\mathrm{SO}_{2}$ concentration (11 September 2008). We first selected routes 1 and 2 along the southeast of the Ring Roads to map the $\mathrm{SO}_{2}$ spatial distribution within the city of Beijing. The Ring Roads cover a wide area from the urban area to the city center and thus it 
Table 1. Mobile measurement dates and route types.

\begin{tabular}{llll}
\hline Cruise Route & Starting date time $\left(\mathrm{LT}^{*}\right)$ & Ending date time (LT) & Route type \\
\hline Route 1 & 20 Aug 2008 (7:58) & 20 Aug 2008 (12:50) & Southeast 2th to 6th Ring RD \\
Route 2 & 4 Sep 2008 (14:13) & 4 Sep 2008 (18:22) & Southeast 4th to 6th Ring RD \\
Route 3 & 3 Sep 2008 (10:05) & 3 Sep 2008 (15:13) & Beijing to Tianjin \\
Route 4 & 11 Sep 2008 (10:09) & 11 Sep 2008 (14:37) & Beijing to Tianjin \\
Route 5 & 6 Aug 2008 (12:00) & 6 Aug 2008 (14:50) & Southwest area outside Beijing \\
\hline
\end{tabular}

* LT: local time.

Table 2. Instrumentation performed in this study.

\begin{tabular}{|c|c|c|}
\hline Station name & Instruments & Measurement species \\
\hline \multirow[t]{2}{*}{ Mobile Laboratory } & $\mathrm{SO}_{2}$ analyzer(Ecotech $9850 \mathrm{~A}$, Austrilia) (10 s) & $\mathrm{SO}_{2}$ \\
\hline & $\begin{array}{l}\text { scanning mobility particle sizer (SMPS) }(3080 \text {, } \\
\text { TSI Inc.) ( } 2 \text { min })\end{array}$ & Size distribution (size $14.1-667 \mathrm{~nm}$ ) \\
\hline \multirow[t]{2}{*}{ PKU station } & $\mathrm{SO}_{2}$ analyzer(Ecotech $9850 \mathrm{~B}$, Austrilia) (1h) & $\mathrm{SO}_{2}$ \\
\hline & Mete One $(1 \sim 3 \mathrm{~h})$ & Wind speed, wind direction \\
\hline \multirow{2}{*}{ YuFa station } & $\mathrm{SO}_{2}$ analyzer(Ecotech $9850 \mathrm{~B}$, Austrilia) (1h) & $\mathrm{SO}_{2}$ \\
\hline & Mete One $(1 \sim 3 \mathrm{~h})$ & Wind speed, wind direction \\
\hline \multirow[t]{2}{*}{ YongLeDian station } & $\mathrm{SO}_{2}$ analyzer(Ecotech $9850 \mathrm{~B}$, Austrilia) (1h) & $\mathrm{SO}_{2}$ \\
\hline & Mete One $(1 \sim 3 h)$ & Wind speed, wind direction \\
\hline CAMS stations & Mete One(1〜3h) & Wind speed, wind direction \\
\hline
\end{tabular}

is preferable to investigate the transport of $\mathrm{SO}_{2}$ at the local scale. Because of the limited battery power of the instruments installed on the platform, observations in the mornings and afternoons were conducted on different days. To illustrate the spatial distribution and transport of $\mathrm{SO}_{2}$ between two megacities (Beijing and Tianjin), we selected a newly built highway (Jingjintang II) between the two cities. The highway was far from industrialized areas, and because it was newly built, it had few cars driving on it during the Olympics. Thus the anthropogenic contribution from vehicular and industrial emissions was low, and the air pollutant levels were comparable to those of background air (Wang et al., 2009a). This unique feature was favorable for studying the air mass transport.

Continuous measurements were also conducted along the southwest of the 5th Ring Road and part of the 6th Ring Road in the southern area, where high-density industry is located, as shown in Fig. 1b (blue line). The characteristics of the $\mathrm{SO}_{2}$ distribution and its local and regional emission sources surrounding the southwest of Beijing have been reported previously (Wang et al., 2009a). Here we added wind field and particle size distribution data for a better understanding the distribution and emission sources of $\mathrm{SO}_{2}$.

\subsection{Ground-based meteorological and $\mathrm{SO}_{2}$ measurements}

Concentrations of $\mathrm{SO}_{2}$ were simultaneously measured at three intensive monitoring stations before, during, and after the Olympics air pollution control period. The PKU station was in an urban station located at Peking University, Beijing $\left(39.99^{\circ} \mathrm{N}, 116.31^{\circ} \mathrm{E}\right)$; $\mathrm{YuFa}\left(\mathrm{YF}, 39.51^{\circ} \mathrm{N}, 116.31^{\circ} \mathrm{E}\right)$ and YongLeDian (YLD, $39.75^{\circ} \mathrm{N}, 116.73^{\circ} \mathrm{E}$ ) were rural stations representing the regional background. They were located approximately $50 \mathrm{~km}$ to the south and southeast of Beijing, respectively. In addition, 11 meteorological stations (blue stars in Fig. 1) of the Chinese Academy of Meteorological Sciences (CAMS) were selected for meteorological data analysis. Table 2 shows measurement parameters and instruments at each station.

To ensure that data between different stations were comparable, the $\mathrm{SO}_{2}$ analyzers (Ecotech, 9850B, Australia) in all the stations were automatically calibrated between 0:00 and 1:00 every day using the same certified calibration standard (50 ppb, accuracy $3 \%$, diluted with $\mathrm{N}_{2}$, Beijing Huayuan Gas Chemical Industry Co., Ltd.). Calibration at five different concentrations $(0 \%, 20 \%, 40 \%$, and $80 \%$ of the detection range) was performed each time. Meanwhile, calibrations of the $\mathrm{SO}_{2}$ analyzer on the mobile laboratory were conducted before and after each sampling trip using similar procedures as at the stations. Intercomparison of $\mathrm{SO}_{2}$ concentrations between the mobile laboratory and PKU station 


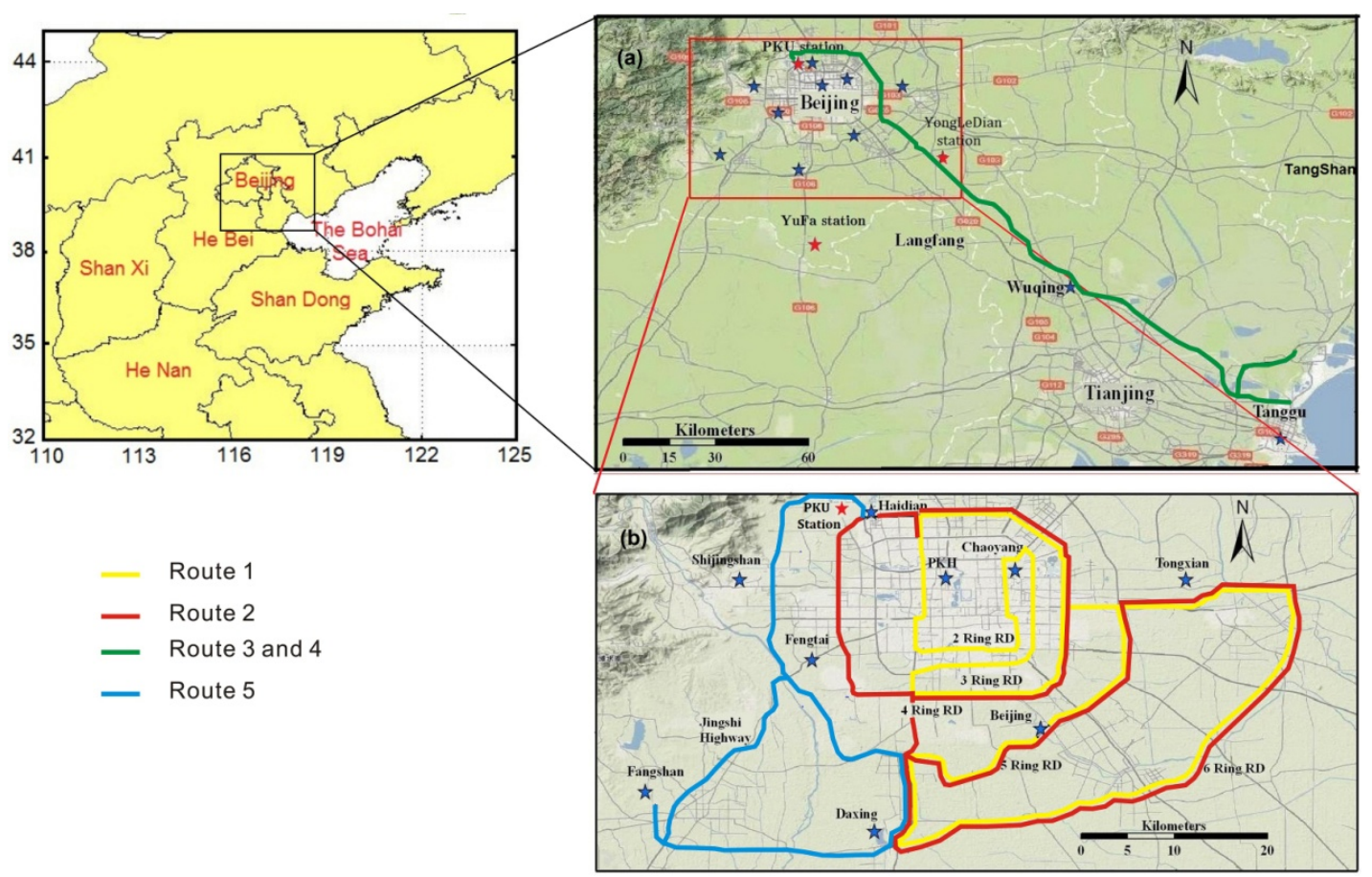

Fig. 1. Maps of the mobile monitoring areas in CAREBeijing-2008. The green track in (a) shows route 3 and 4 in Table 1. The red, yellow and blue tracks in (b) show the route 1, 2 and route 5 respectively. The red stars on the maps represent the stationary sites on $\mathrm{SO}_{2}$ measurements and the blue stars show the CAMS meteorological stations.

was also performed. The difference between the $\mathrm{SO}_{2}$ concentrations was within $15 \%$, with a correlation coefficient of 0.82 (Wang et al., 2009a).

\subsection{Wind field}

\subsubsection{Lagrangian trajectory simulation}

The Hybrid Single Particle Lagrangian Integrated Trajectory model (HYSPLIT, version 4.9), developed by the US National Oceanic and Atmospheric Administration (NOAA) Air Resources Laboratory (ARL), was used to calculate the forward and backward trajectories of plumes from or to the stations in Beijing (Draxler and Rolph, 2003). Backward trajectories were computed once every $6 \mathrm{~h}$ for $24 \mathrm{~h}$ (1 day) at a selected height of $10 \mathrm{~m}$ above ground level for 45 days from 1 August to 15 September, 2008 and were grouped by cluster analysis of the model. A Global Data Assimilation System (GDAS) archive meteorological database was chosen to run the trajectory model, which had $1^{\circ} \times 1^{\circ}$ horizontal resolution. The horizontal resolution of the model is $1^{\circ} \times 1^{\circ}$, which is enough to distinguish the original regions of the air masses in our study.

\subsubsection{Weather Research and Forecasting (WRF) simulation}

Direct measurements of wind speed and wind direction from the mobile lab during driving may lead to large deviations in the estimation of pollutant fluxes (Johansson, 2009). Here we used the WRF model version 3.1.1 to conduct mesoscale meteorological simulations for high-resolution wind fields and planetary boundary layer height (PBL) during the measurement periods. The WRF modeling system is a nextgeneration mesoscale numerical weather forecast and simulation system that includes the Advanced Research dynamics solver. A detailed description of the WRF model can be found on the WRF web-site http://www.wrf-model.org/ index.php, as well as in our supplementary information (SI).

Here the horizontal resolution of the model was $1 \mathrm{~km} \times 1 \mathrm{~km}$. Four domains were used for the WRF calculation (Fig. S1). The averaged concentrations of $\mathrm{SO}_{2}$ were calculated based on each grid unit $(1 \times 1 \mathrm{~km}$ in Fig. $5 \mathrm{a}$, b, $2 \times 2 \mathrm{~km}$ in Fig. 5c, d). The bottom level reaching $18-20 \mathrm{~m}$ above the surface was selected for meteorological analysis. The WRF model can simulate backward trajectories with high spatial resolution, however, to identify the main original locations of the air masses during the measurement period and classify them into regions, it is not necessary to use WRF model for such high resolution tracks as this may take a much longer time than using the Hysplit model. 
Comparing the WRF modeling results with the observations from meteorological stations involved in each domain during the measurement periods, we found close agreement in the wind directions, with Pearson $R=0.83$. The wind speed had a relatively low correlation coefficient $(R=0.66)$ (Fig. S2). This could be attributed to the complicated land use in Beijing in which the local turbulences were not only influenced by the accuracy of the measured data in the meteorological stations (near the ground level where high buildings surround) but also challenge the predictive power of the model. However, given that most of the routes were located in rural areas, we therefore used just the rural sites to calculate the correlation between model and measurements (Fig. S2), and found the correlation coefficient increased significantly both for the wind speed $(R=0.83)$ and wind direction $(R=0.89)$

The WRF model applied the newly updated land use initialized from MODIS and contains high densities of the wind fields in the vertical level (10 layers in 1000m) and horizontal plane ( 1 by $1 \mathrm{~km}$ ). These improvements of the model lead us to believe that the model is able to produce a reliable spatial distribution of the wind field.

Hourly averaged WRF-predicted PBL were compared with the temporal variations of aerosol extinction coefficient retrieved from Lidar measurements (Figs. S3, S4). We selected three days (6, 20 August and 11 September, 2008) with clear sky, well mixed convective condition; the measurement during these days provided sufficiently variable distributions of extinction coefficients. Figures S3 and S4 show that the model- calculated PBL was generally in agreement with the top boundary of the extinction coefficients during the measurement period, even though difference remained. This could be the major source of the flux uncertainty.

\subsection{Assessment of the regional influx of $\mathrm{SO}_{2}$}

Quantitative assessment of $\mathrm{SO}_{2}$ flux has been well established by the design of specified routes encircling target sources (Wang et al., 2006; Rivera et al., 2009; Johansson et al., 2008; Shaiganfar et al., 2011) or crossing frontiers perpendicular to the horizontal wind direction (Beryrich et al., 1998; Matvev et al., 2002). In this study, we carefully designed sector-routes on 20 August (route 1) and 4 September (route 2), so that the mobile tracks would likely traverse the wind direction. To calculate the transport flux outside Beijing, a simple formula based on the above measurement approach with the wind vector towards Beijing was used (White et al., 1976):

$\operatorname{Flux}\left(\mathrm{kg} \mathrm{s}^{-1}\right)=\sum_{i=1}^{n} C_{i}\left(\mu \mathrm{gm}^{3}\right) \cdot V_{i}\left(\mathrm{~ms}^{-1}\right) \cdot \operatorname{Sin} \theta_{i}$

$\cdot H_{i}(m) \cdot d_{i}(m) \times 10^{-9}\left(\mathrm{~kg} \mu \mathrm{g}^{-1}\right)$

where
Flux - the total $\mathrm{SO}_{2}$ flux across the ring road with $n$ $1 \times 1 \mathrm{~km}^{2}$ unit cells $\left(\mathrm{kg} \mathrm{s}^{-1}\right)$

$C_{i}$ - the mean concentration of $\mathrm{SO}_{2}\left(\mu \mathrm{g} \mathrm{m}^{-3}\right)$ in the $i$ th grid $\left(1 \times 1 \mathrm{~km}^{2}\right)$

$\theta_{i}$ - the angle between wind direction and the driving route in the $i$ th $\operatorname{grid}\left(1 \times 1 \mathrm{~km}^{2}\right)$

$V_{i}$ - wind speed $\left(\mathrm{m} \mathrm{s}^{-1}\right)$ in the $i$ th grid $\left(1 \times 1 \mathrm{~km}^{2}\right)$ generated by WRF output

$H$ - mixing layer height $(m)$ in the $i$ th grid $\left(1 \times 1 \mathrm{~km}^{2}\right)$ generated by WRF output

$n$ - total grids $\left(1 \times 1 \mathrm{~km}^{2}\right)$ of each traverse path.

$d_{i}$ - the transect length (m) of the mobile route in the $i$ th grid $\left(1 \times 1 \mathrm{~km}^{2}\right)$.

The principles of the flux calculations have been mentioned in Fig. S5. To estimate fluxes based on Eq. (1), several assumptions were necessary: (1) wind speed and direction were constant during the hour (the hourly mean wind field was used), (2) the atmospheric boundary layer was stable and well-mixed during the measurement period, and the vertical distributions of $\mathrm{SO}_{2}$ concentrations were homogenous, and (3) the wind speed is constant between emission and measurement.

\section{Results and discussion}

\section{1 $\mathrm{SO}_{2}$ concentration time series}

Figure 2 shows the time series of $\mathrm{SO}_{2}$ concentration from the three stations during the air pollution control period. In general, $\mathrm{SO}_{2}$ concentrations were low during the Olympic air pollution control period (8 to 24 August 2008) at all stations, with average values of $5.8 \mathrm{ppb}$ in the city and $3.2 \mathrm{ppb}$ in rural areas. However, there were three periods with high $\mathrm{SO}_{2}$ concentration at all stations: 3-10 August, 19-30 August, and 2-8 September (Fig. 2). During these periods, $\mathrm{SO}_{2}$ concentrations varied dramatically, with diurnal peak levels higher than $15 \mathrm{ppb}$. During the 2008 Beijing Olympics period, most of the $\mathrm{SO}_{2}$ emission sources were strictly controlled within and around Beijing (Wang et al., 2009a) and the reduction of $\mathrm{SO}_{2}$ was estimated to be about $47 \%$ compared with the days before the Olympics; therefore, we assumed that local emission within Beijing city was not a major source of the increase in $\mathrm{SO}_{2}$. Hence regional transport of $\mathrm{SO}_{2}$ under specific meteorological conditions, e.g., wind speed and wind direction, assumed to be the major cause.

To further investigate the possible source(s) of the observed $\mathrm{SO}_{2}, 24-\mathrm{h}$ back trajectories were used to examine the air masses arriving in Beijing during the measurement 


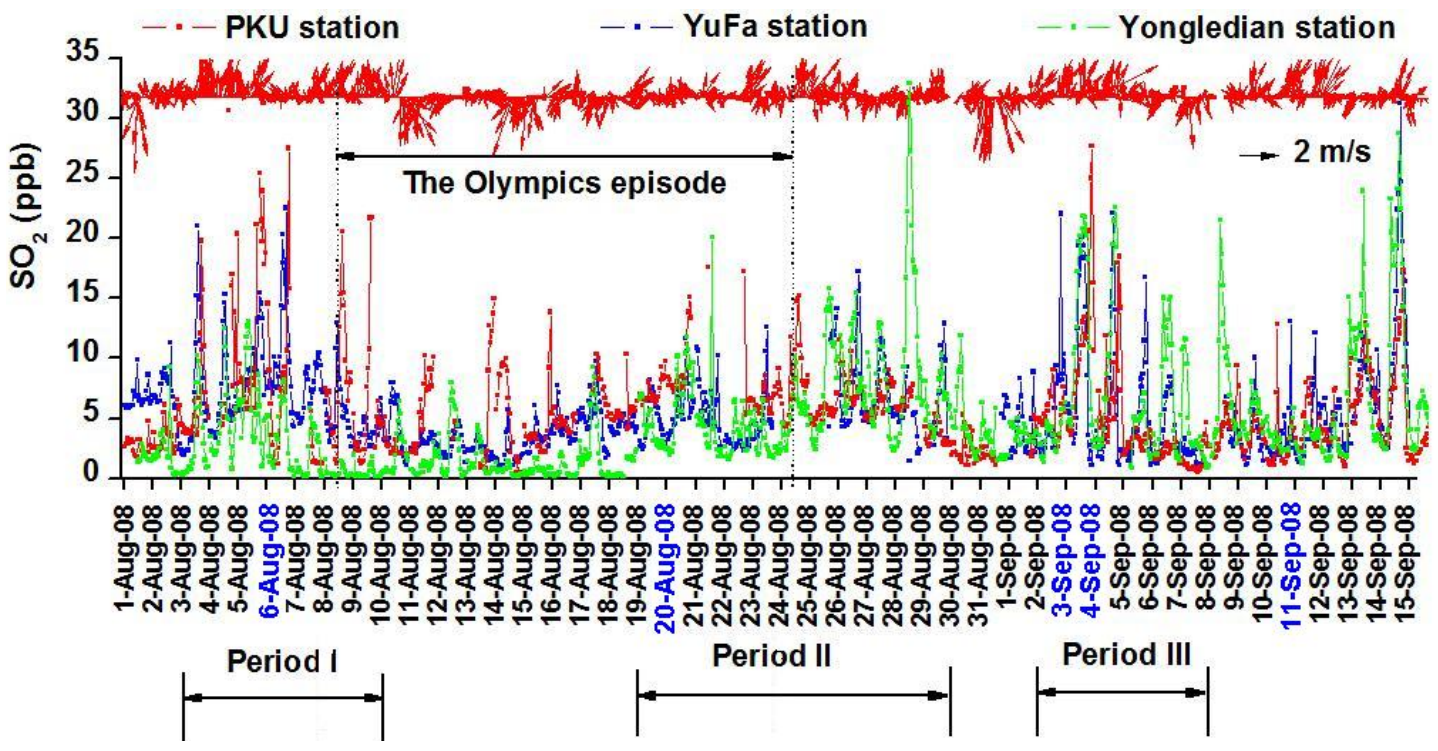

Fig. 2. Temporal variations of $\mathrm{SO}_{2}$ concentrations at PKU, YuFa and YongLeDian stations from 1 August to 15 September 2008 . The reduction of $\mathrm{SO}_{2}$ during the Olympic period was approximately $47 \%$ comparing with the days before the Olympics. The mobile sampling

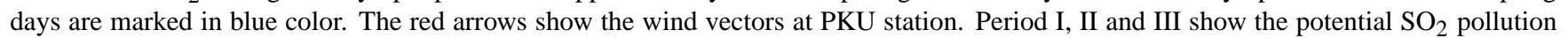
periods with increase trends between 3-10 August, 19-30 August and 2-8 September.

period. A total of 184 trajectories (4 per day) were generated from the center of Beijing and then classified into four groups by cluster analysis. This revealed four typical source regions. Figure 3 shows the three clusters that arose from regional transport outside Beijing. The first group of trajectories (blue) originated from the Bohai Sea in the southeast of China and then moved over the Tianjin and Tangshan areas. The second group (green) was southerly from inland China, passing over Henan and Hebei provinces. The third group (red) was from the northwest of Inner Mongolia and the northeast regions of China. The last group (not shown here) travelled locally around Beijing city. Among the 184 trajectories, clusters 1, 2, 3, and 4 accounted for $22 \%, 28 \%$, $26 \%$, and $24 \%$ of the total trajectory, respectively. The $24-\mathrm{h}$ trajectories of clusters 1 and 2 were short, due to the slow wind speed, and thus $\mathrm{SO}_{2}$ might have accumulated in Beijing. In contrast, the long trajectories of cluster 3 indicated strong winds from the northern area, which brought clean air and were favorable to air dispersion. Figure 4 shows the mean $\mathrm{SO}_{2}$ concentration in Beijing for each trajectory cluster. As expected, high $\mathrm{SO}_{2}$ concentrations were observed on the same days as the trajectory clusters 1 and 2 . The average $\mathrm{SO}_{2}$ concentrations ranged from 5.7 to $7.8 \mathrm{ppb}$. Trajectory clusters 3 and 4 were associated with low $\mathrm{SO}_{2}$ concentrations, which ranged from 3.9 to $4.8 \mathrm{ppb}$, respectively.

Apparently, regional transport played an important role in increasing $\mathrm{SO}_{2}$ concentrations in Beijing. To further investigate the $\mathrm{SO}_{2}$ transport into Beijing, we used three mobile laboratory measurements to provide spatial distributions of $\mathrm{SO}_{2}$ and to quantify its regional influx into Beijing.
$24 \mathrm{~h}$ backward trajectories during the campaign

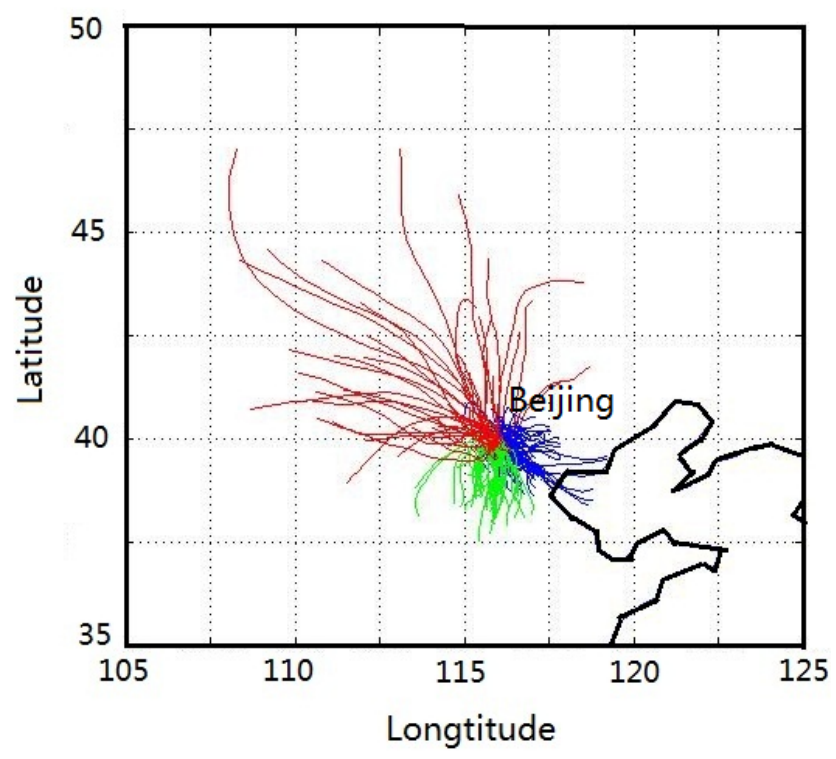

Fig. 3. 24-h Air mass backward trajectories at $10 \mathrm{~m}$ above ground level at Beijing from 1 August to 15 September 2008. The red, green and blue trajectories show the plumes from north, south and southeast regions. 


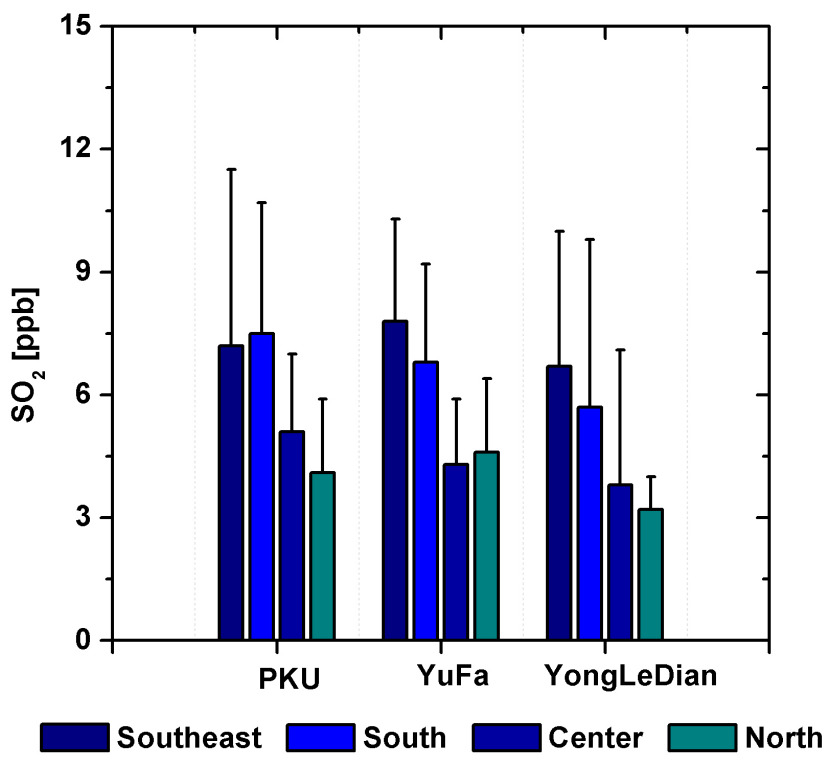

Fig. 4. The average concentrations of $\mathrm{SO}_{2}$ measured at $\mathrm{PKU}, \mathrm{YuFa}$ and YongLeDian sites subdivided on the basis of four directions of backtrajectories from 1 August to 15 September, 2008. The bars show the standard deivations of $\mathrm{SO}_{2}$ concentrations.

\subsection{Case studies of $\mathrm{SO}_{2}$ spatial distribution}

\subsubsection{Southeastern area: routes 1 and 2}

Figure $5 \mathrm{a}$ and $\mathrm{b}$ overlay the $\mathrm{SO}_{2}$ concentrations measured by the mobile laboratory and the wind field generated with the WRF model on 20 August and 4 September. The prevailing winds were from the SE and SSE with speeds of $1.2 \pm 0.2 \mathrm{~m} \mathrm{~s}^{-1}$ and $3.6 \pm 1.2 \mathrm{~m} \mathrm{~s}^{-1}$, respectively. The average mixing boundary layer height was $1027 \pm 232 \mathrm{~m}$ on 20 August and $1223 \pm 48 \mathrm{~m}$ on 4 September (Fig. S4). On both days, $\mathrm{SO}_{2}$ concentrations had apparent horizontal gradients, increasing from urban to rural areas (Fig. 6) and clearly reflecting the transport patterns of $\mathrm{SO}_{2}$ from the source regions in the southern area. Notably, the temporal variations of $\mathrm{SO}_{2}$ emissions may be convoluted with the spatial variability due to the driving speed of the mobile. However, since the wind speeds in both the measuring days were not fast, assuming that the $\mathrm{SO}_{2}$ emissions during measurement period were stable and the air masses were large enough, this influence on the $\mathrm{SO}_{2}$ distributions would be expected low. Figure $5 \mathrm{a}, \mathrm{b}$ show that high $\mathrm{SO}_{2}$ concentrations were observed for approximately $30 \mathrm{~km}$ along the 5th and 6th Ring Roads, implying large-scale air mass transport. The mean value of $\mathrm{SO}_{2}$ on 4 September was $14.9 \pm 3.2 \mathrm{ppb}$, twice as high as the $6.8 \pm 2.1 \mathrm{ppb}$ observed on 20 August

\subsubsection{Southeastern area: routes 3 and 4 between Beijing and Tianjin}

Measurements were also conducted on a larger scale on routes 3 and 4 from Beijing to Tianjin on 3 and 11 September. The wind speeds on both days were similar: $2.38 \pm 0.27 \mathrm{~m} \mathrm{~s}^{-1}$ and $2.04 \pm 0.15 \mathrm{~m} \mathrm{~s}^{-1}$, respectively. The boundary layer was high on 3 September $(1220 \pm 150 \mathrm{~m})$ and relatively low on 11 September $(833 \pm 267 \mathrm{~m})$. The low boundary layer on 11 September is mainly due to the strong inversion layer and the weak wind near the surface. Figure $5 \mathrm{c}$ shows consistent decreasing trends of $\mathrm{SO}_{2}$ concentration from Tianjin to Beijing on 3 September, under southeasterly prevailing winds, indicating the regional transport of $\mathrm{SO}_{2}$ from relatively distant sources. The average $\mathrm{SO}_{2}$ concentrations along route 3 were modestly high, about $23 \mathrm{ppb}$. The maximum $\mathrm{SO}_{2}$ concentration of over $40 \mathrm{ppb}$ was observed in the industrial centers of Tianjin, Tanggu, and Hangu (Fig. 6). In contrast, $\mathrm{SO}_{2}$ concentrations had a very different distribution on 11 September (Fig. 5d), when the northwesterly wind dominated. The $\mathrm{SO}_{2}$ concentrations were low, with an average concentration of around $5 \mathrm{ppb}$ along route 4 (Fig. 6), while $\mathrm{SO}_{2}$ concentrations in Beijing and Tianjin were relatively high. This suggests that $\mathrm{SO}_{2}$ in the cities came mainly from local $\mathrm{SO}_{2}$ emission sources.

\subsubsection{Southwestern area: route 5 surrounding Beijing}

We previously reported high concentrations of $\mathrm{SO}_{2}$ and other pollutants in the Shijingshan district and along Jingkai Highway on 6 August 2008 and suggested this pollution was possibly from both local emission and regional transport (Wang et al., 2009a), but we had no further evidence to support this suggestion. In the particle number size distributions (Fig. 7c), we found bimodality with a remarkably high peak of ultrafine particle number concentrations in the 14.9$100 \mathrm{~nm}$ range and a smaller peak in the range larger than 100 $\mathrm{nm}$, along Jingshi Highway. A similar observation was found in the Shijingshan district, but with lower particle number concentration peaks. Local emissions sources such as traffic exhaust, industrial emission, and biomass burning were identified as the major contributors to the particle number concentrations in the small particle size range, while the larger size particles were "aged," having formed during regional transport. Thus, we believe that the increase in $\mathrm{SO}_{2}$ recorded along Jingshi Highway (Fig. 7b) was caused by both local emissions and regional transport.

To further investigate the high $\mathrm{SO}_{2}$ concentrations in the Shijingshan district, we used the high-resolution wind field from the WRF simulation. As shown in Fig. 7a, on $6 \mathrm{Au}-$ gust the observation along Jingshi Highway was dominated by winds flowing toward the northeast area, with the Shijingshan district located precisely downwind. Pollutants dispersed along the downwind direction from Jingshi Highway, 

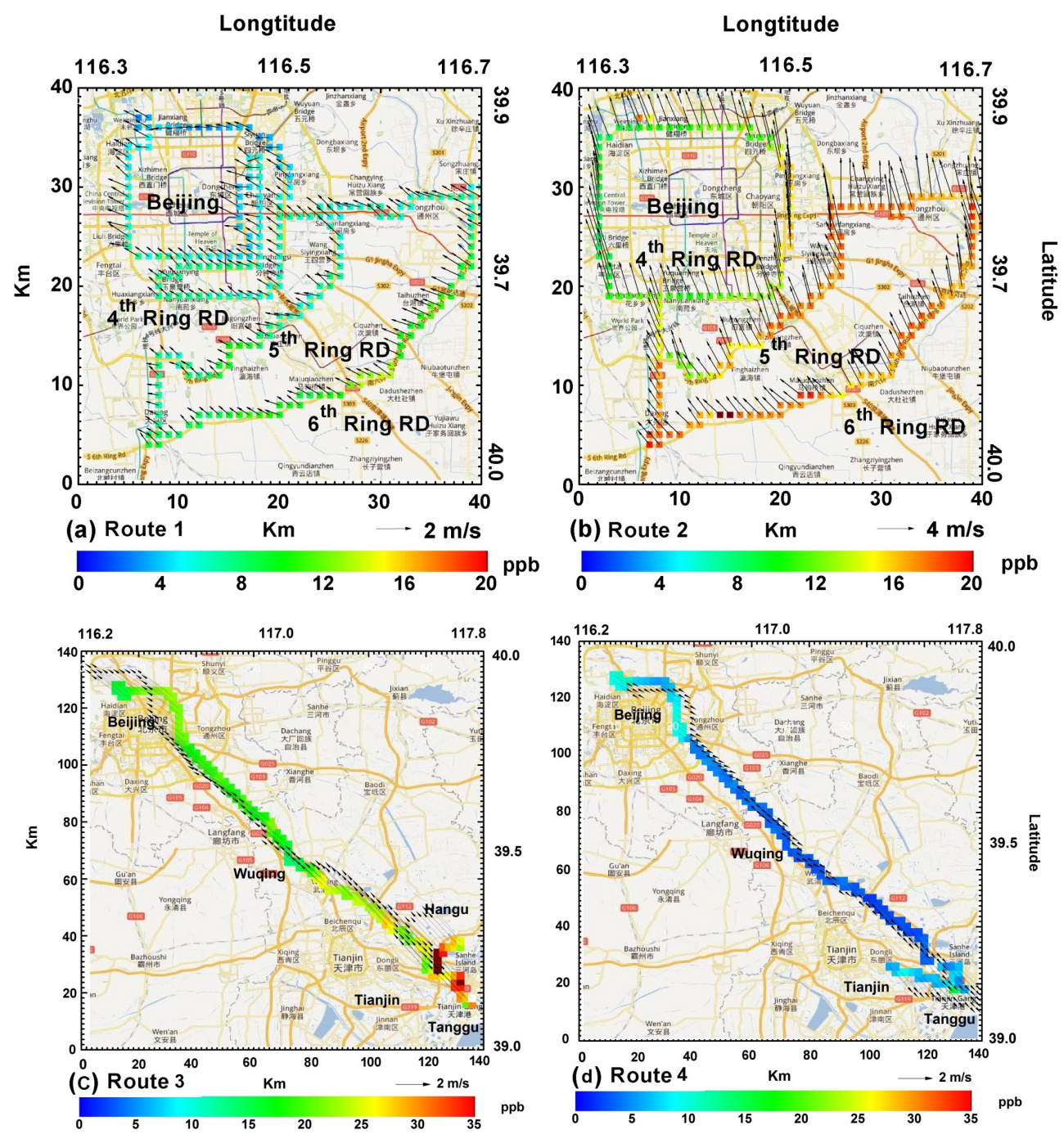

Fig. 5. The spatial distributions of $\mathrm{SO}_{2}$ concentrations and wind field by WRF with $1 \times 1 \mathrm{~km}$ grids resolution in southeastern areas of Beijing on (a) 20 August and (b) 4 September 2008, and $2 \times 2 \mathrm{~km}$ grids from Beijing to Tianjin on (c) 3 September and (d) 11 September 2008 .

leading to a high peak in $\mathrm{SO}_{2}$ concentration across the Shijingshan district (see Fig. 7b dashed boxes).

The first peak of $\mathrm{SO}_{2}$ at Shijingshan section shows clearly an overlap of the local emission and regional transported $\mathrm{SO}_{2}$. We used a simple spline interpolation to separate the $\mathrm{SO}_{2}$ from local emission (shaded area of the first Shijianshan peak in Fig. 7b) and regional transport (underneath the red dots of the first Shijianshan peak in Fig. 7b). The $\mathrm{SO}_{2}$ from local emission was estimated by extracting the regional transport of $\mathrm{SO}_{2}$ from the measured $\mathrm{SO}_{2}$ concentration. With this, we estimated the local emission from Jingshi Highway to the Shijingshan district represented $16 \%$ of the measured $\mathrm{SO}_{2}$ concentrations.

\subsection{Impacts of potential determinants on the measurements}

The mean level of $\mathrm{SO}_{2}$ differed significantly in the southeast of the 4th to 6th Ring Roads between 20 August and 6 September, although the wind field was similar in these days. Several factors might have influenced the variation of $\mathrm{SO}_{2}$ over different days, e.g. variability of the strength of emission sources, prevailing transport directions, and dilutions over time. Figure 8 shows the spatial distributions of $\mathrm{SO}_{2}$ emission during the emission control and non-control period and their emission differences. The emission inventories of Beijing, Tianjin and Hebei provinces were provided by Beijing Environmental Protection Bureau (EPB); for the other regions, we applied East Asia TRACE-P to extend surface sources and INTEX-B for the power plants' emission (Streets et al., 2003; Zhang et al., 2009). Emissions reduction 

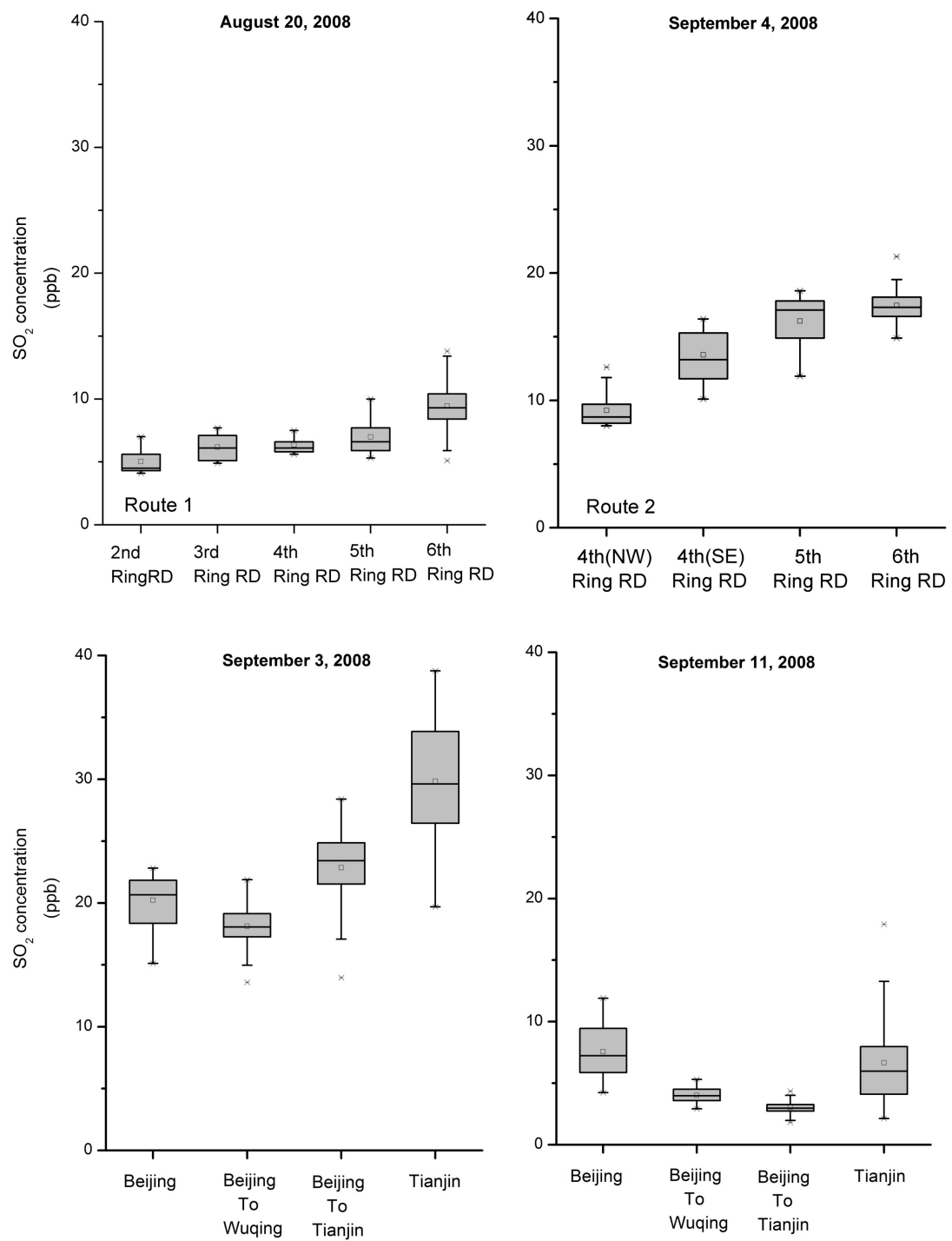

Fig. 6. Boxplots of the $\mathrm{SO}_{2}$ concentrations on the ring roads in southeast of Beijing during the measurement periods. The small block indicates the mean value and the upper, middle and bottom layers of the box show the 75, 50, 25th percentiles of the dataset. The bars are determined by the 5 and 95 th percentiles of the dataset and ' $x$ ' show the maximum and minimum values respectively.

Table 3. $\mathrm{SO}_{2}$ import fluxes and local emission derived from mobile laboratory in different routes surrounding Beijing.

\begin{tabular}{llllll}
\hline & & \multicolumn{4}{c}{$\mathrm{SO}_{2}$ flux $\left(\mathrm{kg} \mathrm{s}^{-1}\right)$} \\
& 4th Ring RD & 5th Ring RD & 6th Ring RD & 5th Ring RD & Shijingshan \\
& SE & SE & SE & SW & \\
6 Aug 2008 & & & & 1.6 & 0.1 \\
20 Aug 2008 & 0.2 & 0.4 & 1.6 & & \\
4 Sep 2008 & 2.1 & 4.0 & 4.6 & & \\
\hline
\end{tabular}

control inventory during the Olympics was mainly based on Beijing EPB emission control policies, taking into account of the desulfurization processes for industries in Beijing and neighboring regions. A high rate of $\mathrm{SO}_{2}$ emissions was gen- erated in the southern area of Beijing and in the Tianjin area which were in agreement with our measurements in Shijingshan area as well as the region southeast to Tianjin. In addition, high emissions were also observed, as expected, in 


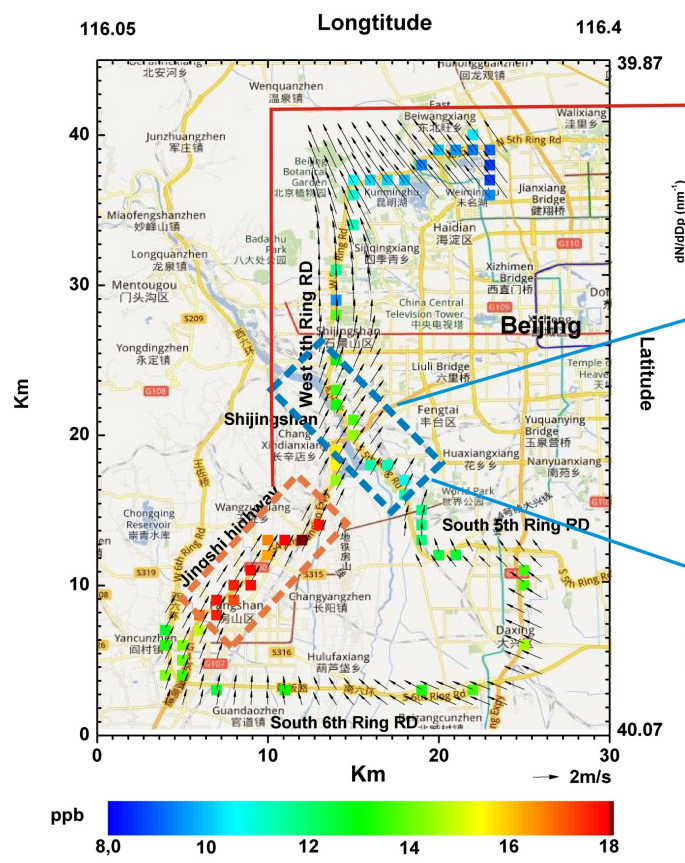

(a)

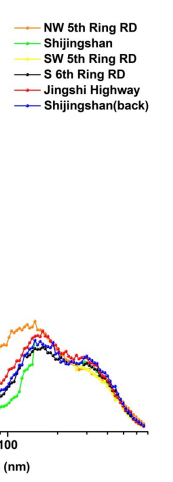

(c)

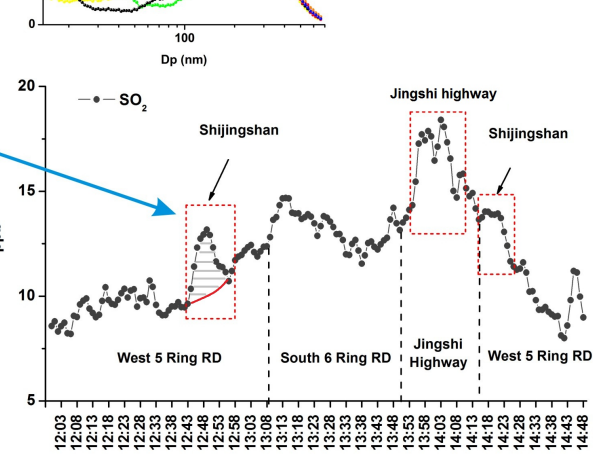

(b)

Fig. 7. (a) $\mathrm{SO}_{2}$ spatial distributions and wind field by WRF with $1 \times 1 \mathrm{~km}^{2}$ grids resolution in southwestern areas of Beijing on 6 August 2008. The dashed areas on the left and middle of the figure represent Jingshi Highway and Shijingshan district where high peak values were observed; (b) time series of $\mathrm{SO}_{2}$ variations on 6 August, where the red plots and the black shades show the regional background and local emission of $\mathrm{SO}_{2}$ across the 5th Ring Road. (c) SMPS particle size distributions measured in seperated areas of the route on 6 August. The red and blue arrows display the Jingshi Highway and Shijingshan districts in (a) corresponding to the $\mathrm{SO}_{2}$ peak values in (b) and the particle size distributions in (c).

Table 4. The annual $\mathrm{SO}_{2}$ emission rates in provinces surrounding Beijing from Beijing EPB and INTEX-B 2006 inventory and the extrapolated $\mathrm{SO}_{2}$ annual flux in our study.

\begin{tabular}{llll}
\hline Province & $\begin{array}{l}\mathrm{SO}_{2} \text { non-control period } \\
\left(\mathrm{Gg} \mathrm{yr}^{-1}\right)\end{array}$ & $\begin{array}{l}\mathrm{SO}_{2} \text { control period } \\
\left(\mathrm{Gg} \mathrm{yr}^{-1}\right)\end{array}$ & Sources \\
\hline Beijing & 200 & 70 & Beijing EPB, 2008 \\
Tianjin & 414 & 324 & Beijing EPB, 2008 \\
Hebei & 1705 & 1316 & Beijing EPB, 2008 \\
Shandong & 3145 & 3145 & INTEX-B 2006 \\
Shanxi & 2995 & 2965 & INTEX-B 2006 \\
Beijing 4th Ring RD & 65.3 & 6.6 & This study \\
Beijing 5th Ring RD & 126.7 & 12.9 & This study \\
Beijing 6th Ring RD & 146.3 & 49.2 & This study \\
\hline
\end{tabular}

the north of Shandong, south of Hebei and east of Shanxi provinces, where many industries are located. In constrast, numerous emissions were partially reduced or completely ceased during the control period. It was apparent that emissions in Beijing and Tianjin were largely and efficiently reduced with a decrease of 2 to $78 \mathrm{Gg} \mathrm{yr}^{-1}$. In addition, most of the area in the south, in Hebei province and in the north, in Shandong province was also widely controlled. Summing up emissions by regions (table 4), Beijing had the highest re- duction rate and lowest emissions of $\mathrm{SO}_{2}$, followed by Tianjin, Hebei, Shanxi and Shandong provinces. Emissions in Beijing decreased from 200 to $70 \mathrm{Gg} \mathrm{yr}^{-1}$ because of the strict and most widely-applied control measures restricting industrial activity and traffic emissions. It was worth noting that emissions in Shandong province under control and noncontrol periods were not different, which does not necessarily indicate no effects of control measures but could reflect a balance between decrease of $\mathrm{SO}_{2}$ in the north and increase 
of $\mathrm{SO}_{2}$ in the south of Shandong. Overall, $\mathrm{SO}_{2}$ emissions were effectively controlled in the south and southeast areas surrounding Beijing, implying spatial variations of emission patterns which were attributed to the concentration differences between 20 August and 4 September.

To investigate the transport sources, the $48 \mathrm{~h}$ backward trajectory of the air mass on 20 August retraced from the Tianjin area and dispersed around the suburban and urban area between Beijing and Tianjin (Fig. 9a). As shown in Fig. 8 and Table 4, the emissions from Tianjin city were much lower than the emissions from the other provinces, hence low $\mathrm{SO}_{2}$ concentrations were to be expected. On 4 September (Fig. 9b), however, the $48 \mathrm{~h}$ backward trajectory originated from the mid-eastern mainland of China, traveling northward across Hebei, Henan, and even Shandong provinces. These areas contain numerous thriving industrialized cities where anthropogenic pollutants, especially $\mathrm{SO}_{2}$, are generated (Streets et al., 2007). Liu et al. (2010) reported that the neighboring provinces around Beijing, such as Shandong, Hebei and Shanxi provinces, contribute a large amount of the total $\mathrm{SO}_{2}$ emissions of China. $\mathrm{SO}_{2}$ emission rate in this area was more than tenfold that of Tianjin. Air masses flowing across these regions usually pick up heavy pollutants downwind, leading to high concentrations of $\mathrm{SO}_{2}$.

$\mathrm{SO}_{2}$ concentration variations may also be influenced by the variability in dilutions in processes of chemical transformations and depositions. The reactions and depositions for $\mathrm{SO}_{2}$ during the transport were different under various meteorological conditions. Low wind speed and relatively high humidity on 20 August was favorable for the transformations of $\mathrm{SO}_{2}$ to sulfate and shortening of the life time in distance travelled. On the contrary, strong wind on 4 September likely decreased the deposition over time. Besides, since the boundary layer on 20 August was not fully developed during the morning sampling period, upwind $\mathrm{SO}_{2}$ sources from power plants may not have fully mixed down to the surface layer, the detrainment of $\mathrm{SO}_{2}$ into the free troposphere of elevated sources from power plant stacks may have led to potential bias of $\mathrm{SO}_{2}$ detection by the measurements.

\subsection{Estimate of $\mathrm{SO}_{2}$ influx to Beijing}

Table 3 lists the flux of $\mathrm{SO}_{2}$ through the Ring Roads on 6 and 20 August and 4 September calculated with Eq. (1), assuming homogenous wind fields. The $\mathrm{SO}_{2}$ flux on the 5th Ring Road on 6 August was determined as $1.6 \mathrm{~kg} \mathrm{~s}^{-1}$, with $2.9 \mathrm{~m} \mathrm{~s}^{-1}$ wind speed and $1140 \pm 233 \mathrm{~m}$ boundary layer height. The flux of local emissions on Jingshi Highway was assessed by calculating the downwind $\mathrm{SO}_{2}$ traverse at the southwestern 5th Ring Road in the Shijingshan district; and yielded a $\mathrm{SO}_{2}$ flux of $0.1 \mathrm{~kg} \mathrm{~s}^{-1}$. The flux of $\mathrm{SO}_{2}$ increased from the 4th to 6th Ring Roads, from 0.2 to $1.6 \mathrm{~kg} \mathrm{~s}^{-1}$ on 20 August, and from 2.1 to $4.6 \mathrm{~kg} \mathrm{~s}^{-1}$ on 4 September. The large difference between the estimated fluxes of $\mathrm{SO}_{2}$ could be explained by the differences in $\mathrm{SO}_{2}$ concentrations and

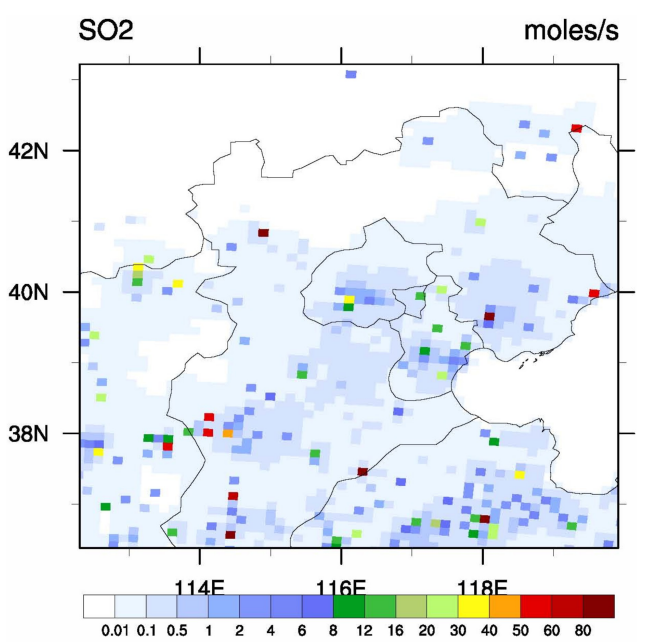

(a)

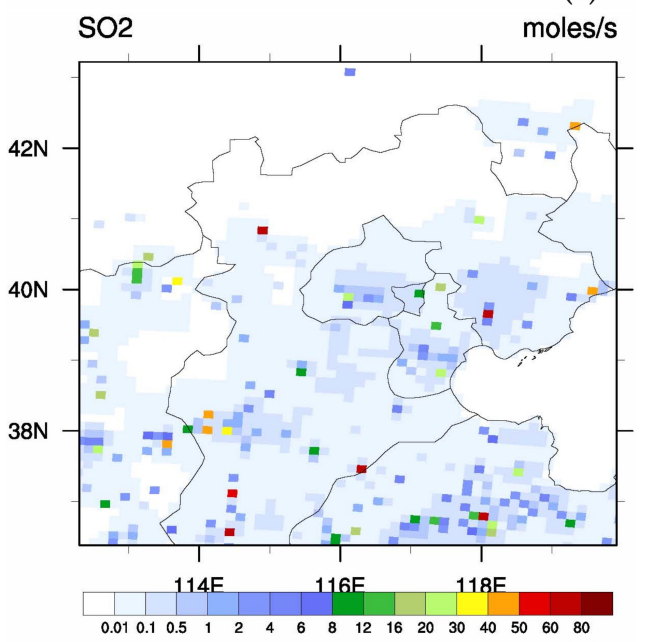

(b)

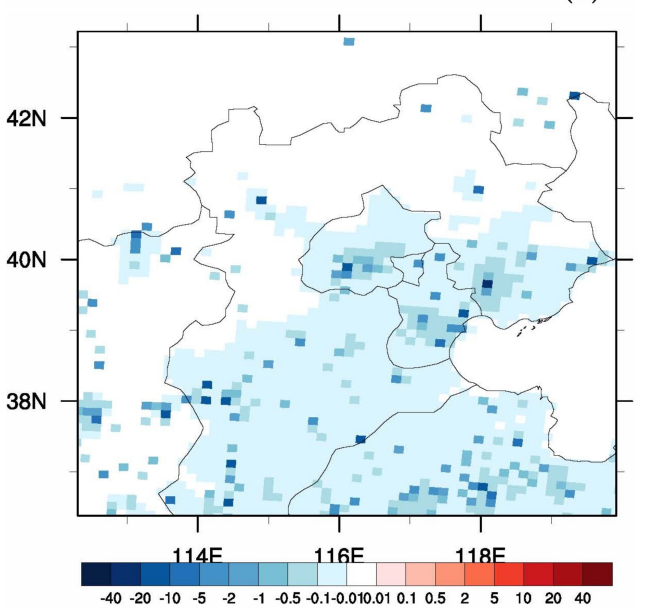

(c)

Fig. 8. Spatial distributions of anthropogenic $\mathrm{SO}_{2}$ in and around Beijing with horizontal resolution of 12 by $12 \mathrm{~km}^{2}$ during the emission (a) non-control and (b) control periods and (c) their differences in between. 
NOAA HYSPLIT MODEL Backward trajectories ending at 0600 UTC 20 Aug 08 GDAS Meteorological Data
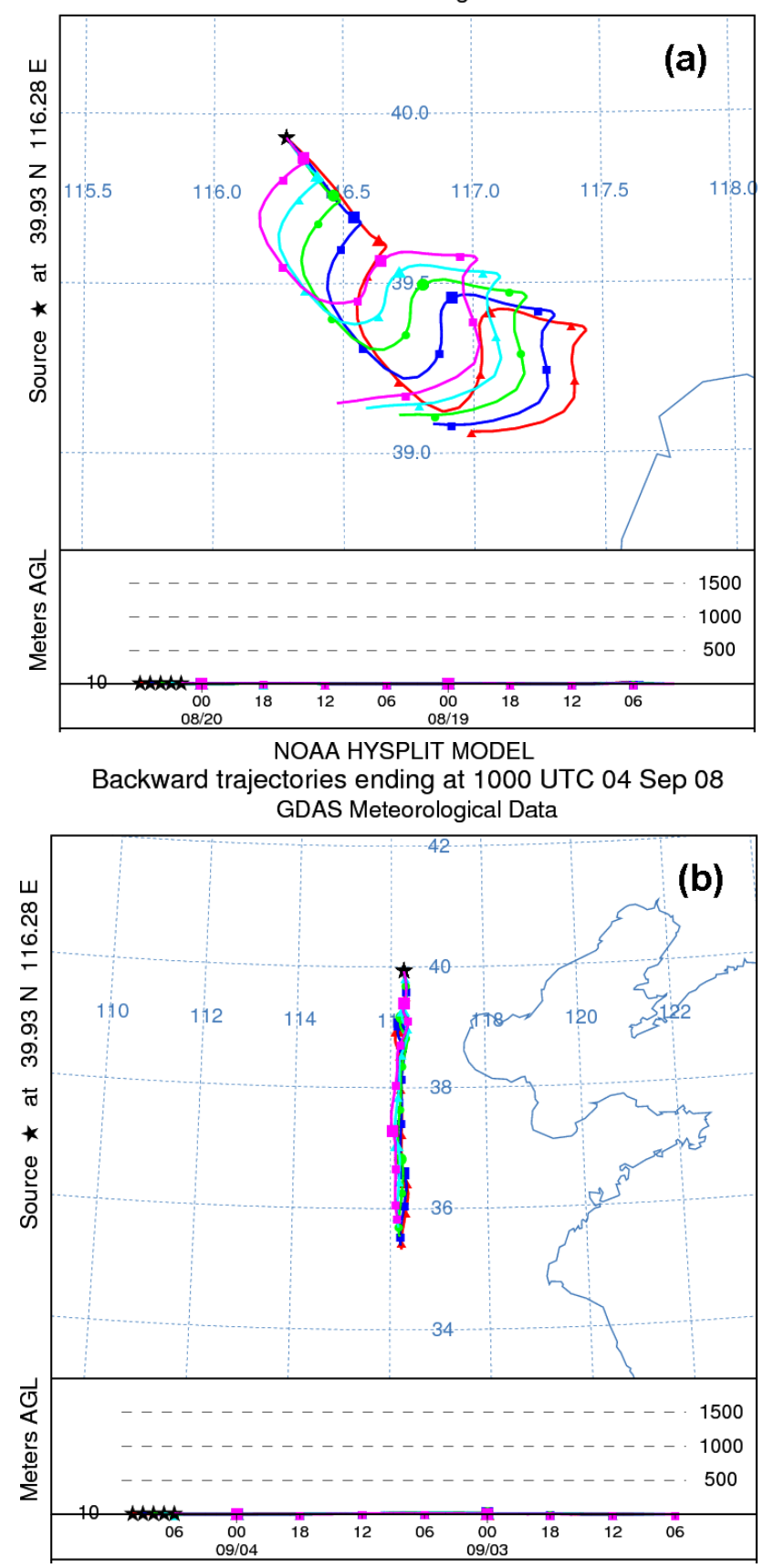

Fig. 9. $48 \mathrm{~h}$ backward trajectories for Beijing on 20 August (a) and 4 September (b), 2008 at a height of $10 \mathrm{~m}$. The multiple tracks (1 track per hour) in figures show the sources during the measurement periods.

meteorological conditions e.g. wind speed and direction between those sampling days. The $\mathrm{SO}_{2}$ concentration variations might be due to abovementioned factors: (1) variations of $\mathrm{SO}_{2}$ spatial patterns during the control and non-control pe- riods; (2) variations of source directions in various emission strength areas, and (3) variations of dilutions over sampling days.

The magnitude of derived influxes through the 6th Ring $\mathrm{Rd}$ is roughly equivalent to a reported single large power plant (Wang et al., 2006) or an industrial complex (Rivera et al., 2009) with emission rates of $2.1 \mathrm{~kg} \mathrm{~s}^{-1}$ and $4.4 \mathrm{~kg} \mathrm{~s}^{-1}$, respectively, regardless of the transformation and deposition processes during the transport. Table 4 compares the emission inventory from Beijing EPB (Wu et al., 2010) and INTEX-B with the calculated $\mathrm{SO}_{2}$ fluxes measured on 20 August and 4 September at the Ring Roads. The calculated $\mathrm{SO}_{2}$ influxes were extrapolated to the annual $\mathrm{SO}_{2}$ influxes by assuming a constant emission rate over a year. It is shown that in the non control period the annual influxes of $\mathrm{SO}_{2}$ through the southeast of the 6th Ring Road into Beijing could be as high as $146.3 \mathrm{Gg} \mathrm{yr}^{-1}$, which is $73 \%$ of the $200 \mathrm{Gg} \mathrm{yr}^{-1}$ annual $\mathrm{SO}_{2}$ emission in Beijing; during the control period, the extrapolated annual influxes of $\mathrm{SO}_{2}$ through the southeast of the 6th Ring Road has been reduced to $49.2 \mathrm{Gg} \mathrm{yr}^{-1}$, but is still $70 \%$ of the extrapolated $70 \mathrm{Gg} \mathrm{yr}^{-1}$ of annual $\mathrm{SO}_{2}$ emission in Beijing. These suggest that within the 6th ring in Beijing the transport of $\mathrm{SO}_{2}$ contributed greatly to the $\mathrm{SO}_{2}$ concentration. Direct comparison between measured data with emission sources seems difficult. Here we applied the SOR index (molar ratio of particulate sulfate to total $\mathrm{SO}_{4}^{2-}+\mathrm{SO}_{2}$ ) for the estimation of $\mathrm{SO}_{2}$ from regional sources, which has been measured in rural Beijing during the summer time in 2006 (Guo et al., 2010). After the transformation, the total influxes of $\mathrm{SO}_{\mathrm{x}}$ in Beijing were estimated to be from 287 to $431 \mathrm{Gg} \mathrm{yr}^{-1}$ in the control period, which was much closer to the emission levels observed in Tianjin. Similarly, estimated SOx was 853 to $1280 \mathrm{Gg} \mathrm{yr}^{-1}$ in the non-control period, which was also comparable to the emissions from Hebei province. However, since all the emissions were calculated regardless of the life time and deposition process, and the derived flux was timedependent and was not representative of the average emissions in years, the yielding emission rates may be underestimated. Apparently, high uncertainties are associated with the $\mathrm{SO}_{2}$ flux measurements and this extrapolation, but our results yield a relative importance of the $\mathrm{SO}_{2}$ transport similar to that previously reported model estimation of a heavy pollution episode (An et al., 2007).

\subsection{Uncertainty}

Uncertainty in estimates of the $\mathrm{SO}_{2}$ flux in this study may come from the sampling strategy, imperfect knowledge in both horizontal and vertical distributions of wind profiles, the height of boundary layers, and the time interval across the plume (Wang et al., 2008). In our study, sampling error due to local turbulences (e.g. street canyon) was minor because most of the routes were located between urban and rural areas which were far away from high buildings. Influences by 
hotspots from vehicles nearby were intentionally avoided by keeping distance $(>10 \mathrm{~m})$ away from vehicles in front. As for the wind field, the horizontal differences in wind speed and direction found by the WRF model were $19 \%$ and $7.5 \%$ compared to the station monitoring data. In addition, using surface wind data for vertical wind profile due to lack of observational information might have underestimated the effectiveness of wind speed for the $\mathrm{SO}_{2}$ influx. However, given that most of the emission sources were located on the surface (except for e.g. power plants), the introduced underestimation is expected to be not so significant (Ibrahim et al., 2010). Regarding $\mathrm{SO}_{2}$ emissions from high stacks, e.g. power plants, it is noteworthy that despite the critical effect of updrafts exchanged in the unstable free atmosphere layer (on 20 August), the estimation error was fairly small considering the long range transport in our cases (Krautstrunk et al., 2000). Zhu et al. (2010) observed a homogeneous vertical distribution of $\mathrm{SO}_{2}$ in daytime in Beijing with DOAS measurements, which suggests our assumption of homogeneous vertical distribution of $\mathrm{SO}_{2}$ is justified. Since observational retrieved extinction coefficients from lidar were not available for every measured period due to meteorological conditions, and single site comparison with the model lacked representations of spatial variation, quantitative errors for the estimated PBL cannot be computed. Qualitatively, the predictive error was about one third. Errors from temporal variations in wind field were relatively low given the smaller spatial scale of the wind fluctuations with respect to the spatial extent of areas of enhanced $\mathrm{SO}_{2}$ concentrations (Ibrahim et al., 2010). A sensitivity analysis indicated approximate $12 \%$ deviations of $\mathrm{SO}_{2}$ fluxes using wind field in individual hours instead of averages. Therefore, the overall error is approximately $31 \%$.

\section{Conclusions}

We used a mobile laboratory to identify and assess the transport processes and emission sources of $\mathrm{SO}_{2}$ surrounding Beijing in combination with the wind field distribution. The measurements were conducted as a part of the CAREBeijing2008 campaign from August to September 2008, and covered the southeast and southwest areas surrounding Beijing.

Continuous measurements at the PKU urban station and the YuFa and YongLeDian rural stations were performed before, during, and after the comprehensive control period. Three potential pollution periods were identified, with short backwards trajectories from the south and southeast areas outside Beijing.

Mobile monitoring was conducted to investigate the regional transport of $\mathrm{SO}_{2}$ from the southern mainland of China. We designed three routes. The route along the southeast of the Ring Roads reflected the wide scope of the polluted plumes, while the "straight line" between Beijing and Tianjin further supported the regional transport of $\mathrm{SO}_{2}$ over long distances. We also noticed that the plumes from the center of mainland China usually picked up pollutants along the way, leading to high concentrations on 4 September compared to those on 20 August. On 6 August, regional transport from southeast areas as well as local emissions on Jingshi Highway and their dispersion over the downwind district of Shijingshan were identified and demonstrated by WRF simulations and particle size-distribution measurements.

Using a simple method assuming constant wind speed and directions within $1 \mathrm{~h}$ and homogeneous vertical profiles of the well-mixed boundary layer, we found that the flux of $\mathrm{SO}_{2}$ transported to Beijing was high on 4 September and low on 20 August. From the 4th to the 6th Ring Roads, the $\mathrm{SO}_{2}$ flux ranged from 2.1 to 4.6 on 4 September and 0.2 to $1.6 \mathrm{~kg} \mathrm{~s}^{-1}$ on 20 August. The difference in influxes between days can be explained by the variability in emissions in areas due to the control policy, the transport directions and the dilution processes on the way. Influx from the southwest on 6 August across the 5th Ring Road was $1.6 \mathrm{~kg} \mathrm{~s}^{-1}$. Local emission on Jingshi Highway was roughly $0.1 \mathrm{~kg} \mathrm{~s}^{-1}$. In summary, mobile monitoring is a useful approach to evaluate temporal and spatial variations in $\mathrm{SO}_{2}$ transport processes. The uncertainty of the $\mathrm{SO}_{2}$ flux is estimated to approximately $31 \%$.

\section{Supplement related to this article is available online at: http://www.atmos-chem-phys.net/11/11631/2011/ acp-11-11631-2011-supplement.pdf.}

Acknowledgements. This study was supported by the Beijing Environmental Protection Bureau (OITC-G08026056). We would like to thank TSI Inc. for their assistance on SMPS instrument support. Special thanks also to the Chinese Meteorological Administration for meteorological data support. We also acknowledge Xiao Tang, Weili Lin and V. C. Lenters for providing precious advice on back trajectory models and data analysis. Finally, we thank NOAA for the data support of the back trajectory model.

Edited by: D. Parrish

\section{References}

An, X., Zhu, T., Wang, Z., Li, C., and Wang, Y.: A modeling analysis of a heavy air pollution episode occurred in Beijing, Atmos. Chem. Phys., 7, 3103-3114, doi:10.5194/acp-7-3103-2007, 2007.

Beijing Statistical Yearbook: China Statistics Press, Beijing, China, chapter 4.2, 2009.

Beryrich, F., Grafe, H., Kuchler, W., Lindemann, C., and Schaller, E.: An obervational study of sulphur dioxide transport across the erzgebirge mountains, Atmos. Environ., 32, 1027-1038, 1998.

Brunekreef, B. and Holgate, S. T.: Air pollution and health, Lancet, 360, 1233-1242, 2002.

Bukowiecki, N., Dommen, J., Prevot, A. S. H., Richter, R., Weingartner, E., and Baltensperger, U.: A mobile pollutant measurement laboratory-measuring gas phase and aerosol ambient concentrations with high spatial and temporal resolution, Atmos. Environ., 36, 5569-5579, 2002. 
Canagaratna, M. R., Jayne, J. T., Ghertner, D. A., Herndon, S., Shi, Q., Jimenez, J. L., Silva, P. J., Williams, P., Lanni, T., Drewnick, F., Demerjian, K., Kolb, C. E., and Worsnop, D. R.: Chase Studies of Particulate Emissions from in-use New York City Vehicles, Aerosol Sci. Technol., 38, 2004,

Ding, A. J., Wang, T., Xue, L. K., Gao, J., Stohl, A., Lei, H. C., Jin, D. Z., Ren, Y., Wang, X. Z., Wei, X. L., Qi, Y. B., Liu, J., and Zhang, X. Q.: Transport of north china air pollution by midlatitude cyclones: Case study of aircraft measurements in summer 2007, J. Geophys. Res.-Atmos., 114, D11399, doi:10.1029/2009jd012339, 2009.

Draxler, R. R. and Rolph, G. D.: Hysplit (hybrid single-particle lagrangian integrated trajectory) model access via noaa arl ready website http://www.Arl.Noaa.Gov/ready/hysplit4.html, NOAA Air Resources Laboratory, 2003.

Guo, S., Hu, M., Wang, Z. B., Slanina, J., and Zhao, Y. L.: Sizeresolved aerosol water-soluble ionic compositions in the summer of beijing: Implication of regional secondary formation, Atmos. Chem. Phys., 10, 947-959, doi:10.5194/acp-10-947-2010, 2010.

Hebei Statistical Yearbook, China Statistics Press, Beijing, China, Sect. 9.2, 2009.

Herndon, S. C., Jayne, J. T., Zahniser, M. S., Worsnop, D. R., Knighton, B., Alwine, E., Lamb, B. K., Zavala, M., Nelson, D. D., McManus, J. B., Shorter, J. H., Canagaratna, M. R., Onasch, T. B., and Kolb, C. E: Characterization of urban pollutant emission fluxes and ambient concentration distributions using a mobile laboratory with rapid response instrumentation, Faraday Discuss., 130, 327-339, 2005.

Ibrahim, O., Shaiganfar, R., Sinreich, R., Stein, T., Platt, U., and Wagner, T.: Car MAX-DOAS measurements around entire cities: quantification of $\mathrm{NO}_{\mathrm{x}}$ emissions from the cities of Mannheim and Ludwigshafen (Germany), Atmos. Meas. Tech., 3, 709-721, doi:10.5194/amt-10-709-2010, 2010.

Johansson, M., Galle, B., Yu, T., Tang, L., Chen, D., Li, H. J., Li, J. X., and Zhang, Y.: Quantification of total emission of air pollutants from beijing using mobile mini-doas, Atmos. Environ., 42, 6926-6933, 2008.

Johansson, M., Rivera, C., de Foy, B., Lei, W., Song, J., Zhang, Y., Galle, B., and Molina, L.: Mobile mini-doas measurement of the outflow of $\mathrm{NO}_{2}$ and $\mathrm{HCHO}$ from mexico city, Atmos. Chem. Phys., 9, 5647-5653, doi:10.5194/acp-9-5647-2009, 2009.

Krautstrunk, M., Neumann-Hauf, G., Schlager, H., Klemm, O., Beyrich, F., Corsmeier, U., Kalthoff, N., and Kotzain, M.: An experimental study on the planetary boundary layer transport of air pollutants over East Germany, Atmos. Environ., 34, 12471266, 2000

Li, A., Xie, P. H., Liu, W. Q., Liu, J. G., Dou, K.: Studies on the determination of the flux of gaseous pollutant from an area by passive differential optical absorption spectroscopy, (in Chinese), Spectrosc. Spect. Analys., 29, 28-32, 2009.

Li, C., Krotkov, N. A., Dickerson, R. R., Li, Z. Q., Yang, K., and Chin, M.: Transport and evolution of a pollution plume from Northern China: A satellite-based case study, J. Geophys. Res.Atmos., 115, D00K03, doi:10.1029/2009jd012245, 2010.

Liu, J., Zhang, X. L., Xu, X. F., and Xu, H. H.: Comparison analysis of variation characteristics of $\mathrm{SO}_{2}, \mathrm{NO}_{\mathrm{x}}, \mathrm{O}_{3}$ and $\mathrm{PM}_{2.5}$ between rural and urban areas, Beijing, Environ. Sci., 29, 10591065,2008

Liu, Z., Street, D. G., Zhang, Q., Wang, S., Carmichael, G. R.,
Cheng, Y. F., Wei, C., Chin, M., Diehl, T., and Tan, Q.: Sulfur dioxide emissions in China and sulfur trends in East Asia since 2000, Atmos. Chem. Phys., 10, 6311-6331, doi:10.5194/acp-106311-2010, 2010

Matsui, H., Koike, M., Kondo, Y., Takegawa, N., Kita, K., Miyazaki, Y., Hu, M., Chang, S. Y., Blake, D. R., Fast, J. D., Zaveri, R. A., Streets, D. G., Zhang, Q., and Zhu, T.: Spatial and temporal variations of aerosols around beijing in summer 2006: Model evaluation and source apportionment, J. Geophys. Res.Atmos., 114, D00G13, doi:10.1029/2008JD010906, 2009.

Ma, J. Z., Chen, Y., Wang, W., Yan, P., Liu, H. J., Yang, S. Y., Hu, Z. J., and Lelieveld, J.: Strong air pollution causes widespread haze-clouds over China, J. Geophys. Res.-Atmos., 115, D18204, doi:10.1029/2009JD013065, 2010.

Matvev, V., Dayan, U., Tass, I., and Peleg, M.: Atmospheric sulfur flux rates to and from israel, The Science of the Total Environment 291, 143-154, 2002.

Ohara, T., Akimoto, H., Kurokawa, J., Horii, N., Yamaji, K., Yan, X., and Hayasaka, T.: An asian emission inventory of anthropogenic emission sources for the period 1980-2020, Atmos. Chem. Phys., 7, 4419-4444, doi:10.5194/acp-7-4419-2007, 2007.

Qin, M., Xie, P. H., Wu, D. X., Xu, J., Si, F. Q., Wang, M. H., Dou, K., Zhang, Y., Xiao, X., Liu, W. S., Liu, S. S., Wang, F. P., Fang, W., Liu, J. G., and Liu, W. Q.: Investigation of variation characteristics and levels of $\mathrm{SO}_{2}-\mathrm{NO}_{2}-\mathrm{O}_{3}$ and pm10 in Beijing during 2008 Olympic Games, J. Atmos. Environ. Opt., 4, 329340, 2009.

Ramanathan, V. and Crutzen, P. J.: New directions: Atmospheric brown "Clouds", Atmos. Environ., 37, 4033-4035, 2003.

Rivera, C., Sosa, G., Wohrnschimmel, H., de Foy, B., Johansson, M., and Galle, B.: Tula industrial complex (mexico) emissions of $\mathrm{SO}_{2}$ and $\mathrm{NO}_{2}$ during the MCMA 2006 field campaign using a mobile mini-doas system, Atmos. Chem. Phys., 9, 6351-6361, doi:10.5194/acp-9-6351-2009, 2009

Shaiganfar, R., Beirle, S., Sharma, M., Chauhan, A., Singh, R. P., and Wagner, T.: Estimation of $\mathrm{NO}_{\mathrm{x}}$ emissions from Delhi using Car MAX-DOAS observations and comparison with OMI satellite data, Atmos. Chem. Phys., 11, 10871-10887, doi:10.5194/acp-11-10871-2011, 2011.

Shandong Statistical Yearbook, China Statistics Press, Beijing, China, chapter 6-2, 2009

Shanxi Statistical Yearbook, China Statistics Press. Beijing, China, chapter 4.10, 2009.

Streets, D., Bond, T., Carmichael, G., Fernandes, S. D., Fu, Q., He, D., Klimont, Z., Nelson, S. M., Tsai, N. Y., Wang, M. Q., Woo, J. H., and Yarber, K. F.: An inventory of gaseous and primary aerosol emission in Asia in the year 2000, J. Geophys. Res.Atmos., 108, 8809, doi:10.1029/2002JD003093, 2003.

Streets, D. G., Fu, J. S., Jang, C. J., Hao, J. M., He, K. B., Tang, X. Y., Zhang, Y. H., Wang, Z. F., Li, Z. P., Zhang, Q., Wang, L. T., Wang, B. Y., and Yu, C.: Air quality during the 2008 beijing olympic games, Atmos. Environ., 41, 480-492, 2007.

Sun, Y., Wang, Y. S., and Zhang, C. C.: Measurement of the vertical profile of atmospheric $\mathrm{SO}_{2}$ during the heating period in Beijing on days of high air pollution, Atmos. Environ., 43, 468-472, 2009.

Sun, Y. L., Zhuang, G. S., Wang, Y., and Han, L. H.: The airborne particulate pollution in beijing-concentration, composition, dis- 
tribution and sources, Atmos. Environ., 38, 5991-6004, 2004.

Tianjin Statistical Yearbook, China Statistics Press. Beijing, China, chapter 5.1, 2009.

Wang, M., Zhu, T., Zheng, J., Zhang, R. Y., Zhang, S. Q., Xie, X. X., Han, Y. Q., and Li, Y.: Use of a mobile laboratory to evaluate changes in on-road air pollutants during the beijing 2008 summer olympics, Atmos. Chem. Phys., 9, 8247-8263, 2009a, http://www.atmos-chem-phys.net/9/8247/2009/.

Wang, P., Richter, A., Bruns, M., Burrows, J. P., Scheele, R., Junkermann, W., Heue, K. P., Wagner, T., Platt, U., and Pundt, I.: Airborne multi-axis DOAS measurements of tropospheric $\mathrm{SO}_{2}$ plumes in the PO-valley, Italy, Atmos. Chem. Phys., 6, 329-338, doi:10.5194/acp-6-329-2006, 2006.

Wang, W., Ren, L. H., Zhang, Y. H., Chen, J. H., Liu, H. J., Bao, L. F., Fan, S. J., and Tang, D. G.: Aircraft measurements of gaseous pollutants and particulate matter over pearl river delta in china, Atmos. Environ., 42, 6187-6202, 2008.

Wang, Y., Hao, J., McElroy, M. B., Munger, J. W., Ma, H., Chen, D., and Nielsen, C. P.: Ozone air quality during the 2008 beijing olympics: Effectiveness of emission restrictions, Atmos. Chem. Phys., 9, 5237-5251, doi:10.5194/acp-9-5237-2009, 2009b.

Weijers, E. P., Khlystov, A. Y., Kos, G. P. A., and Erisman, J. W.: Variability of particulate matter concentrations along roads and motorways determined by a moving measurement unit, Atmos. Environ., 38, 2993-3002, 2004.

White, W. H., Anderson, J. A., Blumenthal, D. L., Husar, R. B., Gillani, N. V., Husar, J. D., and Wilson, W. E.: Formation and transport of secondary air pollutants: ozone and aerosols in the St. Louis urban plume, Science, 194, 187-189, 1976.
$\mathrm{Wu}, \mathrm{Q} . \mathrm{Z}$.: Developing and applying multiple air quality prediction modeling system for Beijing, dipl. thesis, 76-78, 2010.

$\mathrm{Xu}, \mathrm{X}$. D., Zhou, L., and Zhou, X. J.: Urban environment region influenced by surrounding sources during serious atmospheric pollution process, Sci. China D Earth Sci., 34, 958-966, 2004.

Xu, X. P., Wang, L. H., and Niu, T. H.: Air pollution and its health effects in beijing, Ecosyst. Health, 4, 199-209, 1998.

Zhang, M. G., Uno, I., Yoshida, Y., Xu, Y. F., Wang, Z. F., Akimoto, H., Bates, T., Quinn, T., Bandy, A., and Blomquist, B.: Transport and transformation of sulfur compounds over east asia during the trace-p and ace-asia campaigns, Atmos. Environ., 38, 69476959, 2004a.

Zhang, Q., Streets, D. G., Carmichael, G. R., He, K. B., Huo, H., Kannari, A., Klimont, Z., Park, I. S., Reddy, S., Fu, J. S., Chen, D., Duan, L., Lei, Y., Wang, L. T., and Yao, Z. L.: Asian emissions in 2006 for the NASA INTEX-B mission, Atmos. Chem. Phys., 9, 5131-5153, doi:10.5194/acp-9-5131-2009, 2009.

Zhang, Z. G., Gao, Q. X., and Han, X. Q.: The study of pollutant transport between the cities in north china, Res. Environ. Sci. 17, 14-20, 2004b.

Zhu, Y. W., Liu, W. Q., Xie, P. H., Dou, K., Qin, M., and Si, F. Q.: Monitoring and analysis for vertical profiles of air pollutants in boundary layer of Beijing (in Chinese), Chinese J. Geophys., 53, 1278-1283, 2010. 